コンファレンスレポート

\title{
「1986年レーザーと光学結晶に関する国際シンポジウム」報告 ならびに「中国における光学結晶の現状」
}

\section{佐々木孝友}

\author{
Reports on "1986 International Symposium on Laser \\ and Optical Crytals" and "Development of Optical Crystals \\ in China",
}

Takatomo SASAKI

\section{1. まえがき}

昭和61年10月 9 日〜 12 日の間中国上海で開催 された「1986年レーザーと光学結晶に関する国 際シンポジウム」に参加した。また上海, 福州 等のレーザー用結晶, 非線形光学結晶を製作し ている研究所を訪問し, 中国における光学結晶 開発の現状を視察した。

一言で云って非常に結晶作りの盛んな国であ る。YAGロッドなら国内で50ケ所以上で作っ ているという話しである。このように熱心な理 由として, レーザーが国家推進主要研究テーマ の一つになっていることが上げられよう。また 結晶育成は高価な最新式測定器をずらりと並べ る訳でなく割と安い予算でできることと, 育成 には常時人間の観測が必要であり，人的資源が 豊富なことから，非常に都合のよい研究テーマ になったと思われる。新製品を開発した場合に は, 国や市からの表彰の対象になると同時に予 算獲得ができるようになっており, 各研究所が 競って結晶づくりに励んでいる状況である。こ のため結構オリジナルな仕事も多い。最近話題 の紫外線発生用バリウムボレート結晶, 有機の LAP 結晶等は中国が生み出した結晶である。
また米国では育成がむずかしいと云うことで殆 んどやめてしまっている尿素結晶も数 $\mathrm{cm}$ 角のも のを作っている研究所が二, 三ある。YAG レ ーザーの二倍高調波発生用高効率 $\mathrm{KTP}$ 結晶も 米国より大きなものができているということで ある。その他新しいレーザー素材の研究も大変 活発に行なわれている。

以下ではまず国際シンポジウムの状況をのべ たあと, 学会で興味のあった発表について, 研 究所の紹介を兼ねながら報告する。

\section{2. 国際シンポジウム概要}

会議の主催は中国硅酸塩学会, 中国光学会, Chairman は上海光学精密机械研究所の干福喜 (Gan Fuxi) 教授であったcまた会議のテーマは レーザー用結晶成長技術, 結晶評価, 新レーザ 一材料, レーザー技術他である。中国国内にお いてはレーザー結晶の研究者が多数おり,この 関係の国際会議を中国々内で行えるということ で第 1 回の会議を企画したものらしいが, 外国 への宣伝が不十分なことと, 準備時間不足のた めに, 外国人出席者はわずか 13 名であった。内 訳は日本 6 , 米国 3 , ソ連 2 , 西独 1 , 英国 1 である。日本人の内訳は無機材研の木村茂行先

*大阪大学工学部電気工学教室（T565 吹田市山田丘 2-1)

* Department of Electrical Engineering, Faculty of Engineering, Osaka University (2-1 Yamadaoka, Suita City) 
Table I Main Chinese institutes which attended on the symposium.

\section{(上海)}

$\bigcirc$ 上海光学精密机械研究所

Shanghai Institute of Optics and Fine Mechanics ○上海硅酸塩研究所

Shanghai Institute of Ceramics

○上海激光技術研究所

Shanghai Institute of Laser and Technology (北京)

\section{$\bigcirc$ 物理研究所}

Institute of Physics

$\bigcirc$ 华北光電研究所

North China Research Institute of Electro-Optics ○人工晶体研究所

Research Institute of Synthetic Crystals

(済南)

○山東大学晶体材料研究所

Shandon University, Institute of Crystal Materials (福州)

\section{○福建物質結構研究所}

Fujian Institute of Research and the Structure of Matter

(南京)

○南京大学固体物理研究所

Nanjin University, Institute of Solid State Physics (合肥)

$\bigcirc$ 安徽光学精密机械研究所

Anfui Institute of Optics and Fine Mechanics (長春)

○長春光学精密机械研究所

Changchun Institute of Optics and Fine Mechanics ○長春応用化学研究所

Changchun Institute of Applied Chemistry

生，筆者を含め阪大より 2 名他は企業の方々で あった。中国国内からの出席者を含めると合計 100 名程度の会議であった。会議の規模として は小さく国内会議の英語版発表という印象はあ つたが，内容的にはずいぶん新しい報告があっ た。Table I に中国々内の主要参加研究所の リストを示す。

会議と併行して展示会が催され，育成，製作 したレーザー結晶, 非線形結晶を販売すべく各 研究所が製品の展示を行なっていた。Fig. 1 に
展示会の様子を示す。展示品の中には驚くほど 大きな結晶も出されていた。Fig. 1（b）は直径 $18 \mathrm{~cm}$ の大大 $\mathrm{LiNbO}_{3}$ 単結晶である。学会で報 告のあつた新材料も製品として展示されていた。 製品説明は会議の発表者が行なっていた。

\section{3. 学会報告}

\section{1 上海光机所}

この研究所は1964年長春光机所から独立した レーザー研究所で, 全体で1400名, うちResearcher は600名, Technitian 400名である。 レーザー核融合, レーザー同位体分離, 各種レ 一ザー，レーザー材料開発を行なっている。レ ーザー結晶関係は研究者数約50名, (1) YAG,

(2) New YAG, (3) Alexandrite, (4) Fiber, (5) Characterization, (6)Chemistryの 6 グル

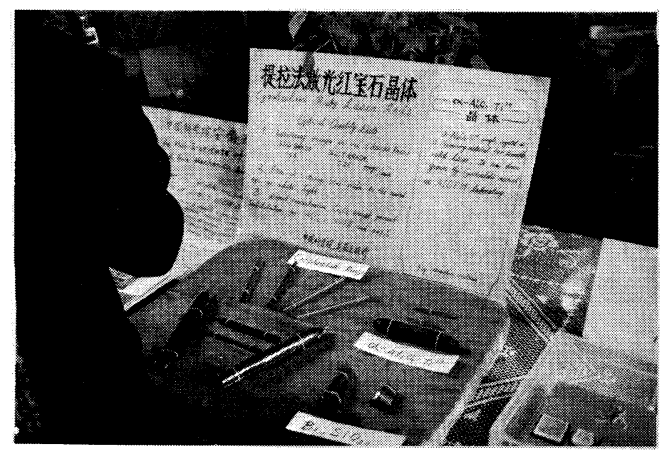

(a)

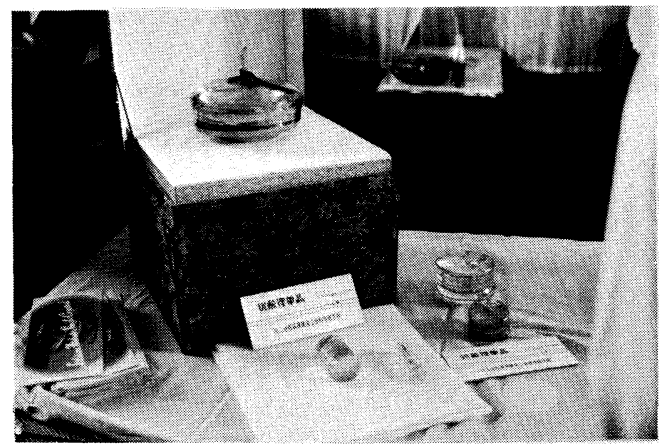

(b)

Fig. 1 Exhibition of laser crystals

(a) Ruby rods and $\mathrm{Ti}$ doped sapphire rods $\left(10 \mathrm{~mm}^{\Phi} \times 200 \mathrm{~mm}^{l}\right)$

(b) $\mathrm{LiNbO}_{3}$ crystals (diameter $18 \mathrm{~cm}$ ) and $\mathrm{LiTaO}_{3}$ crystals. 
ープに分れている。

\subsubsection{Coreless YAG}

YAG 結晶は 高繰返し高出力を得るためのスラ ブ型レーザー用に極めてすぐれた特性を有して いるが通常，育成時結晶中心にコアと称する欠 陷部が生じるため大口径のものを得るのが困難 である。そこでコアのない結晶を育成し大口径 のものを得る研究が開始されている。上海光机 所ではNewYAGのグループがこれを担当して おり，今回発表を行なった。詳しい製法に関し ては秘密であるが，大略は以下の通りである。

育成法は “Static temperature gradient technique”と名づけられており，従来のチェ コラフスキー法による育成に比し極めてゆっく り育成するもので，約 1 ケ月かけ直径 $60 \sim 75 \mathrm{~mm}$, 長さ $130 \mathrm{~mm}$ 位いのものを得ていた。育成方位は 通常の方位と同じ〈111〉でモリブデン炉を用い $1826^{\circ} \mathrm{C}$ ありで育成するとのことであった。 $\mathrm{Nd}^{3+}$ は0.7〜2.3 wt \%の高濃度まで添加でき,スラブ 型レーザーに適している。育成の歩留りは現在 の所 $50 \%$ 位いということで，失敗すると大きな クラックが入ってしまう。Fig. 2 は $\mathrm{He}-\mathrm{Ne}$ ーザーによる育成結晶の径方向透過干渉波面(a) とスラブ状に切り出した板の干渉波面(b)を示す。 周辺 3 ケ所に欠陥が見られるが中心部は欠陥が ないことが分る。Fig. 3 は結晶内の $\mathrm{Nd}^{3+}$ 量の 分布を示す。育成ロッドが長くなるにつれ $\mathrm{Nd}^{3+}$ 量が減少してゆく傾向にある。

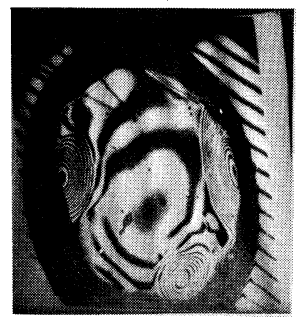

(a)

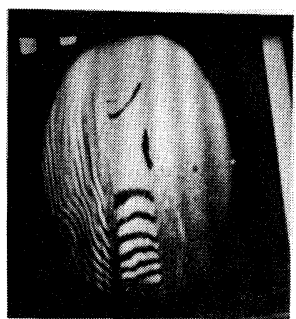

(b)
Fig. 2 Interferograms of coreless YAG rod (a) as-grown crystal (diameter $\sim 60 \mathrm{~mm}$ ) (b) slab plate.

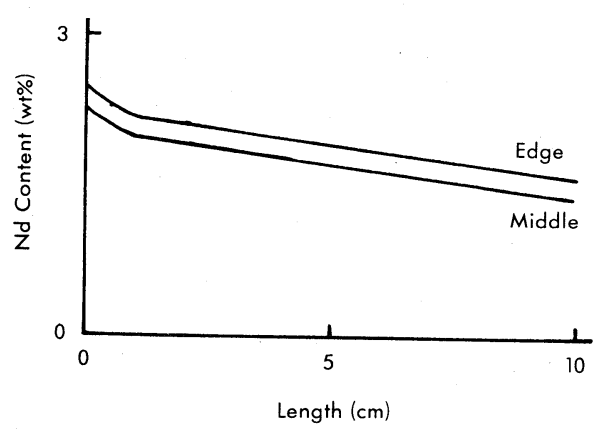

Fig. 3 Distribution of $\mathrm{Nd}^{3+}$ in grown crystal

3.1.2 新チューニング材料 ( $\left.\mathrm{BHA}: \mathrm{Cr}^{3+}\right)$ 固体チューニングレーザーとして，最下， Alexandrite, Emerald が盛んに研究されてい るが, これに代る新チューニング材料として BHA : $\mathrm{Cr}^{3+}$ (Beryllium Hexa-Aluminate, $\left.\mathrm{Be} \mathrm{Al}_{6(1-\mathrm{x})} \mathrm{Cr}_{6 \mathrm{x}} \mathrm{O}_{10}\right)$ を育成, その特性が報告

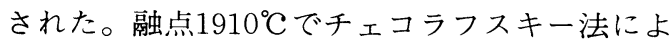
り直径 $2 \mathrm{~cm}$, 長さ数 $\mathrm{cm}$ 程度の結晶を得ている。 Alexandrite よりもチューニング幅が広い, 熱 伝導が大きいという特長を持つ。 Fig.4に Alexandrite と比較した蛍光スペクトルを示す。 まだ発振作用は得ていないようだが，新材料と して注目される。

\section{1 .3 その他}

上海光机所では YAGロッド製作と共にAlexandrite $\left(\mathrm{Cr}^{3+}: \mathrm{BeAl}_{2} \mathrm{O}_{4}\right)$ にも力を入れている。 現在直径 $3 \mathrm{~cm}$, 長さ $10 \mathrm{~cm}$ の大型結晶が育成でき ている。

$$
\text { 光学ファイバーとして炭酸ガスレーザー伝播 }
$$

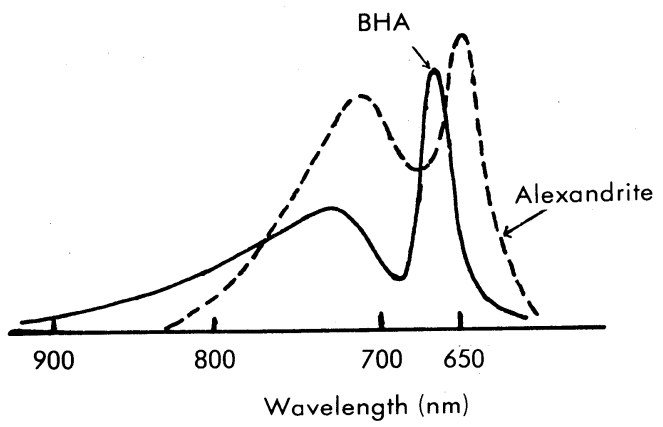

Fig. 4 Emission spectrum of $\mathrm{BHA}: \mathrm{Cr}^{3+}$ crystal 
用のKRS 5 の報告があった。タテ型ブリッジマン 法で1.5 2. $5 \mathrm{~mm} / 1$ 時間の割で引き抜く。直径 0.5 $1 \mathrm{~mm}$, 長さ最大 $5 \mathrm{~m}$ のポリクリスタルフ アイバーが製作できる。 $\mathrm{OH}^{-}, \mathrm{SO}_{4}^{--}, \mathrm{NO}_{3}^{--}$, $\mathrm{HCO}_{3}^{-}$等の陰イオン混入を時に少なくしており， $10.6 \mu \mathrm{m}$ での減衰量は $0.5 \mathrm{~dB} / \mathrm{m}$ ということ である。応用に医用メス，レーザー加工を目指 している。

\section{2 福建物質結構研究所}

福建省福州にあるこの砰究所は1960年設立で, 現在全体で540名，うち370名がResearcher と Technitian である。化学関係の研究者が多く, 結晶に関する理論, 解析から育成製作まで一貫 して研究を行なっている。2 年前の IQEC (Santa Ana) でChen 教授により発表された紫外線発生 用 $\mathrm{Ba} \mathrm{B}_{2} \mathrm{O}_{4}$ 結晶を生み出した研究所である。 彼等はこの成果に対し中国科学院より「科技成 果一等奖」の彰賞を受けている。筆者が訪問し た時には国内外にこの結晶を販売するための大 量生産用建物を建設中であり, 大变活気に満ち ていた。今回福建研究所からの学会報告は一件 と少なかったが, 溶融結晶から無機, 有機水溶 性結晶に至る各種の新結晶を活溌に研究してい た。

\subsection{1 新 $\mathrm{Nd}$ レーザー材料 (NAB)}

$\mathrm{Nd}^{3+}$ 添加の.Aluminium Borate $\left[\mathrm{Nd}^{3+}: \mathrm{Al}_{3}\right.$ $\left(\mathrm{BO}_{3}\right)_{4}$ ]を NAB と呼んでおり, Flux 法で育成 $20 \times 20 \times 45 \mathrm{~mm}^{3}$ の結晶を得ている。結晶の対称 性がR 32 のもの以前に ATT ベル研究所が報 告しており，基本波と二倍高調波を同時に発生 させる，いわゆる Multi-function 用結晶の可 能性を有するものであったが，今回開発したも のは C $2 \mathrm{C}$ 構造で基本波発振用のみであるが, YAGよりも高出力を得ることができた。直径 $3.2 \mathrm{~mm}$ ×長さ $23.7 \mathrm{~mm}$ のロッドを用い小型フ ラッシュランプ励起により, 波長 $1.063 \mu \mathrm{m}$ で 出力 $1.2 \mathrm{~J}$ を得ている。
3.2.2 Ytterium Aluminium Perovskite (Nd: YAP)

この結晶は発振波長 $1.079 \mu \mathrm{m} の \mathrm{YAG}$ に似 た $\mathrm{Nd}^{3+}$ 添加レーザー材料である。今回新たに開発 されたものではなく以前からあるものだが，特長 としてYAGの $3 \sim 6$ 倍のスピードで育成でき 3 日で $30 \mathrm{~cm}$ 位いの長さのものを引き上げること ができる長所を有している。しかし粘性がYAG よりも高いため光学的特性が悪くアメリカでは 実用化されなかった。この研究所で沾粘性の改 良を行ない良質のものを得るのに成功している。 彼等はこれにより「科技成果二等奨」を受けた。 直径 $5.8 \mathrm{~mm}$ X長さ $111 \mathrm{~mm}$ のロッ゙で連続出力 80W (波長 $1.34 \mu \mathrm{m}$ ) が得られている。また直 径 $9 \mathrm{~mm} \times 150 \mathrm{~mm}$ のロッドでは連続300 W( 波長 $1.079 \mu \mathrm{m})$ は出せるとのことであった。

\section{2 .3 その他}

紫外線発生用 $\beta-\mathrm{BaB}_{2} \mathrm{O}_{4}$ 結晶は $5 \mathrm{~mm}$ 角程度 のものが販売のため量産体制に入っている。さ らに大型の結晶を得る研究が行なわれているよ うであるが，まだ成果の報告はない。

有機結晶では $29 \times 13 \times 71 \mathrm{~mm}^{3}$ の大型尿素結晶 を見ることができた。この結晶も潮解性はある が紫外線発生には大変魅力的な結晶である。研 究所の話しではこの 4 倍の大きさのものでも製 作可能であるとの事であった。この他DDS, pMHB 等の新しい有機結晶の研究も行なわれて いる。X線回折用結晶としては $10 \mathrm{~cm}$ 角近い

$\mathrm{KAP}, \mathrm{PET}, \mathrm{TAM}$ 等を製作していた。

無機結晶の $\mathrm{KDP}$ は $20 \mathrm{~cm}$ 角 $\times$ 高さ $40 \mathrm{~cm}$ 位い のものが最大のようであった。主として上海光 机所のレーザー核融合部門へ波長変換素子用と して製作，販売している。DKDP は10 cm 角の ものが作られていた。

\section{3 山東大学晶体材料研究所}

この研究所も結晶製作に関しては極めてActive で, 特に非線形光学結晶を対象に, 溶融引き上 げ結晶, Flux 結晶, 有機, 無機結晶のあらゆ る結晶を手がけている。 


\subsection{1 有機非線形光学結晶 (LAP)}

この結晶は1981年に山東大学で始めて発表さ れたもので, LAPはL-Arginine Phosphate monohydrate の略, 構造式は $\left(\mathrm{NH}_{2}\right)_{2}^{+} \mathrm{CNH}$ $\left(\mathrm{CH}_{2}\right)_{3} \mathrm{CH}\left(\mathrm{NH}_{3}\right)^{+} \mathrm{COO}^{-} \cdot \mathrm{H}_{2} \mathrm{PO}_{4}^{-}$である。諸特 性をTable II に示す。

（1）水溶液から育成するので大型のものが作 れる見込みがある。

（2）結晶が化学的に安定かつ湿気に強い

（3）レーザー損傷閾值が高い

（4）紫外線発生が可能

（5） KDP より波長変換効率が高い

等の点からレーザー核融合波長変換用に都合 が良いということで米国リバーモア研究所も研 究を開始している。('86 CLEO San Fransiscoで発表） 結晶育成サイズは現在の所最大 $40 \times 40 \times 50 \mathrm{~mm}^{3}$ である。今回は紫外域へのレー ザー波長変換実験の結果を報告した。TadleiIII に位相整合角，変換効率等をまとめたものを 示す。Mode-locked YAG Laser を用いた時 には $2 \omega$ から $4 \omega$ への変換効率として $\eta=38.9$ \%の高効率が得られている。この結晶はレーザ 一光の入射方向を工夫することにより 1 ケの結 晶を用いるだけで， $2 \omega, 3 \omega, 4 \omega$ の高調波光 を取り出すことができる。この様子をFig. 5 に 示す。

Table II Properties of LAP crystal.

$\begin{array}{ll}\text { Structure } & :\left(\mathrm{NH}_{2}\right)_{2} \mathrm{CHN}\left(\mathrm{CH}_{2}\right)_{3} \mathrm{CH}\left(\mathrm{NH}_{3}\right) \\ & \mathrm{COO} \cdot \mathrm{H}_{2} \mathrm{PO}_{4} \\ & : \mathrm{a}=10.85 \AA . \mathrm{A}, \mathrm{b}=7.91 \AA \\ \mathrm{c}=7.32 \AA\end{array}$

Chemically inert

Moisture free

Growth from solution

\begin{tabular}{|c|c|}
\hline Melting point & $140^{\circ} \mathrm{C}$ \\
\hline Transmission region & $: 220 \mathrm{~nm} \sim 1940 \mathrm{~nm}$ \\
\hline High nonlinear coefficient & 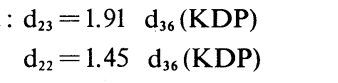 \\
\hline Laser damage threshold & $\begin{aligned}: & >1 \mathrm{GW} / \mathrm{cm}^{2} \\
& (10 \mathrm{~ns}, \mathrm{Q}-\text { switched YAG) }\end{aligned}$ \\
\hline
\end{tabular}

TableIII Phase matching angles and wavelength conversion efficiency of LAP crystal.

(Q-switched YAG laser, $6 \mathrm{ns,} 200 \mathrm{~mJ}$ )

$\begin{array}{cclc}\text { Harmonics } & \begin{array}{c}\text { Phase matching } \\ \text { angle }\end{array} & \begin{array}{c}\text { Crystal } \\ \text { thickness }\end{array} & \begin{array}{c}\text { Conversion } \\ \text { efficiency }\end{array} \\ 2 \omega & \theta=52^{\circ} \varphi=30^{\circ} & 1.3 \mathrm{~cm} & 12 \% \\ 3 \omega & \theta=32^{\circ} \varphi=0^{\circ} & 2.6 \mathrm{~cm} & 16 \% \\ 4 \omega & \theta=62^{\circ} \varphi=49^{\circ} & 0.65 \mathrm{~cm} & 18 \%\end{array}$

(Mode-locked YAG laser, $0.2 \mathrm{~ns}, 80 \mathrm{~mJ}$ )

$$
4 \omega \quad \theta=62^{\circ} \quad \varphi=49^{\circ} \quad 0.65 \mathrm{~cm} \quad 38.9 \%
$$
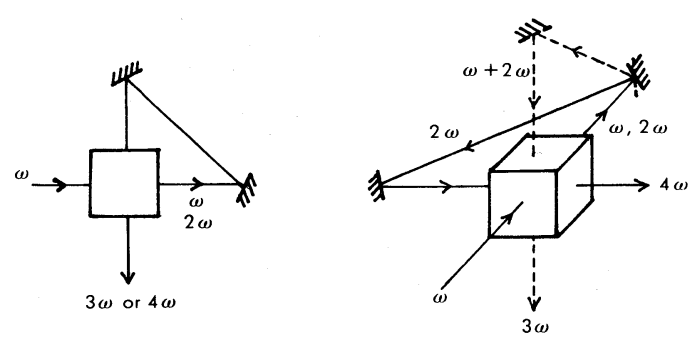

Fig. 5 Multi-frequency conversion devices

(a) Two frequencies, $\theta=67^{\circ}, \varphi=56.5^{\circ}$

(b) Three frequencies, $\theta=118^{\circ}, \varphi=132^{\circ}$

\subsection{2 高出力紫外線発生用有機金属結晶}

高出力紫外線発生用有機結晶 LAP の次の新 結晶の開発が精力的に行なわれている。非線形 光学結晶としては非対称性を有する多面体構造 を持つ物質が有望である。この種の構造を持つ ものとして有機金属結晶 (Organo metallic complex crystal) が極めてすぐれているとい う。今回報告された結晶は $\mathrm{Cd}\left(\mathrm{NH}_{2} \mathrm{CSNH}_{2}\right)_{2} \mathrm{Cl}_{2}$ (略して BTCC) でその特性を Table IVに示す。 $10 \times 10 \times 20 \mathrm{~cm}^{3}$ のサイズの結晶育成に成功して いる。レーザー特性はまだ計測されていない。

\subsubsection{Multi-function Crystal (NYAB)}

基本波発生と同時に二倍高調波発生を同一の 結晶で実現する（Multi-function）試みは以前 からあったが，今回世界で始めて実験に成功し た。NYABは $\mathrm{Nd} \times \mathrm{Y}_{1-\mathrm{x}} \mathrm{Al}_{3}\left(\mathrm{BO}_{3}\right)_{4}$ の略である。 育成パラメータを Table V に示す。Quantel社 の色素レーザー（波長 $587.5 \mathrm{~nm}$ ）を用い, 断 
Table IV Properties of BTCC crystal.

\begin{tabular}{|c|c|}
\hline Structure & $: \mathrm{Cd}\left(\mathrm{NH}_{2} \mathrm{CSNH}_{2}\right)_{2} \mathrm{Cl}_{2}$ \\
\hline Nonlinear coefficient & $:$ deff $=2.75 \mathrm{~d}_{36}(\mathrm{KDP})$ \\
\hline Transmission region & $: 285 \mathrm{~nm} \sim 500 \mathrm{~nm}$ \\
\hline Growth method & : Solution \\
\hline Gravity & $: 2.32 \mathrm{~g} / \mathrm{cc}$ \\
\hline Size & $: \operatorname{Max} 10 \times 10 \times 20 \mathrm{~mm}^{3}$ \\
\hline
\end{tabular}

Table V Properties of NYAB crystal.

$\begin{array}{ll}\bigcirc \text { Structure } & : \mathrm{Nd}_{\mathbf{x}} \mathrm{Y}_{1-\mathrm{x}} \mathrm{Al}_{3}\left(\mathrm{BO}_{3}\right)_{4} \\ \text { Growth method } & : \text { Flux } \\ \text { Flux } & : \mathrm{K}_{2} \mathrm{Mo}_{3} \mathrm{O}_{10}, \mathrm{Li}_{2} \mathrm{~B}_{4} \mathrm{O}_{7}+\mathrm{B}_{2} \mathrm{O}_{3} \\ \text { Melting point } & : 1180 \pm 10{ }^{\circ} \mathrm{C} \\ \text { Saturation temperature } & : 1040{ }^{\circ} \mathrm{C} \pm 5{ }^{\circ} \mathrm{C} \\ \text { Temperature fall rate } & : 2 \sim 5{ }^{\circ} \mathrm{C} / \text { day } \\ \text { Nonlinear coefficient } & : \mathrm{d}_{11}=3.9 \mathrm{~d}_{36}(\mathrm{KDP}) \\ \text { Size } & : 15 \times 10 \times 10 \mathrm{~mm}^{3}\end{array}$

面 $5 \times 3 \mathrm{~mm}^{2}$, 厚さ $3 \mathrm{~mm}$ の NYAB を励起, $2 \omega$ (green light) 出力 $5 \mathrm{~mJ}$, 変換効率 $10 \%$ を得て いる。

\section{3 .4 その他}

この研究所ではこの他 $\mathrm{KTP}$ 結晶の量産を行 なっている。結晶寸法は断面 $8 \times 8 \mathrm{~mm}^{2}$, 厚み $3 \sim 5 \mathrm{~mm}$, 育成法はFlux 法で20〜30台の装置 を用いているとのことである。

KDP 結晶もレーザー核融合研究が進展して 来たので断面 $20 \mathrm{~cm}$ 以上のものを育成開始すると のことである。尿素結晶も数 $\mathrm{cm}$ 角のものができ る。

\section{4 北京物理研究所}

今回はレーザー結晶 $\mathrm{GGG}: \mathrm{Nd}: \mathrm{Cr}(\mathrm{Gd} \cdot \mathrm{Ga}$ ・ Garnet）の組成改造について報告があった。 $\mathrm{GSGG}(\mathrm{Gd} \cdot \mathrm{Sc} \cdot \mathrm{Ga} \cdot \mathrm{Garnet})$ はGGGに比しレ ーザー結晶としては優れているが, Sc が極め て高価かつ入手困難という問題がある。そこで $\mathrm{GGG}$ の組成に $\mathrm{Ca}, \mathrm{Mg}, \mathrm{Zr}$ を添加し GSGG のレーザー作用に近い, 安価な材料を得ようと するものである。チェコラフスキー法で直径 50 $\mathrm{mm}$ ×長さ $60 \mathrm{~mm}$ もものを引き上げレーザー特性
を調べている。

今回報告はなかったが, この研究所は直径 20 〜30 mm の KTP 結晶を最近製作できるように なった事で注目されている。育成に水熱法を採 用しているが従来の方法では 3,000 気圧, 数 100 ${ }^{\circ} \mathrm{C}$ 以上の条件が必要であった。最近 1,000 気圧 以下で育成できる方法が見つかったため大型 $\mathrm{KTP}$ 結晶が作れるようになったとの事である。 ただし新技術自体は米国で開発されたものらし い。

他に大型 $\mathrm{LiIO}_{3}$ 結晶も製作している。

\section{5 华北光電研究所}

この研究所は全体で 1,500 名, うち結晶関係 の研究者は70名である。(1)YLF，(2) YAG（40 名), (3)GSGG, (4) $\mathrm{LiNbO}_{3}$, (5)バナナ, (6) KDP, (7) $\beta-\mathrm{BaB}_{2} \mathrm{O}_{4}$, (8) Laser device and application の 8 つグループに分かれている。

GSGG グループからは物理研究所と同じよ うに $\mathrm{Ca}, \mathrm{Mg}, \mathrm{Zr}$ を添加した $\mathrm{GGG}$ 結晶の報告 があった。

バナナ結晶は直径 $10 〜 20 \mathrm{~mm} \times$ 長さ $50 \mathrm{~mm}$ の大型 のものが育成されている。

また最近 $\beta-\mathrm{BaB}_{2} \mathrm{O}_{4}$ 結晶の育成を福建研究 所についで開始しており, 直径 $15 \mathrm{~mm} \times$ 厚さ $7 \mathrm{~mm}$ のものができるということである。

\section{6 安徽光机所}

チューニングレーザー用 Alexandrite（Be $\mathrm{Al}_{2} \mathrm{O}_{4}$ : $\left(\mathrm{Cr}^{3+}\right)$ 結晶の発表があった。結晶特性, レーザー特性をTable 6 に示す。直径 $18 \mathrm{~mm} \times$ 長さ $90 \mathrm{~mm}$ の良質の結晶が得られている。この 他 Alexandrite は $\mathrm{Be}_{2} \mathrm{O}_{3}$ が猛毒, またはGSGG は Sc が高価ということで, その代替品として 新素材 $\mathrm{YGG}\left(\mathrm{Y}_{3} \mathrm{Ga}_{5} \mathrm{O}_{12}: \mathrm{Cr}^{3+}\right)$ 結晶を Flux 法 で開発中であり，このスペクトル特性の報告が あった。

\section{7 その他の研究所}

上海硅酸塩研究所には約 1,000 名のメンバー。 がおり, New inorganic non-metallic材料の研 
Table VI Properties of Alexandrite crystal.

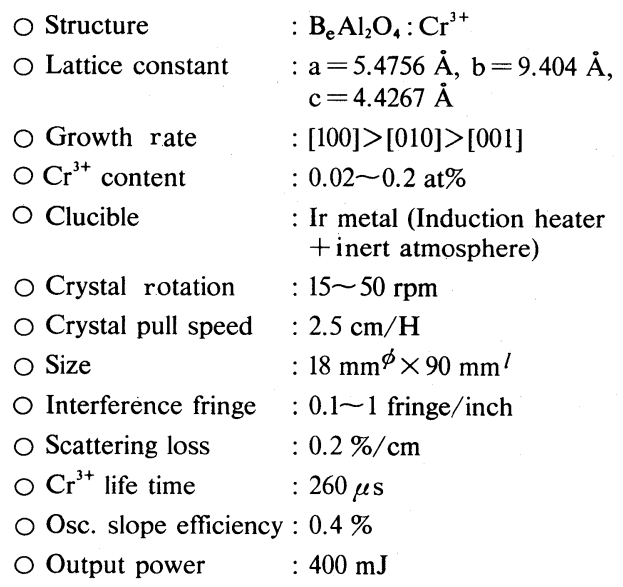

究を行なっている。シンチレータ用 $\mathrm{BGO}$ (Bismuth Germanate), 電気光学用 $\mathrm{LiNbO}_{3}$, 音響 用 $\mathrm{LiTaO}_{3}, \mathrm{TeO}_{2}, \mathrm{PbMoO}_{4}$ 等は大型のものが 供給できる。また二倍高調波発生用バナナ結晶 として直径 $25 \mathrm{~mm} \times$ 長さ $60 \mathrm{~mm}$ の超大型のものが
展示してあった。

長春光机所は $\mathrm{CaF}, \mathrm{LiF}, \mathrm{BaF}_{2}, \mathrm{CaCO}_{3}$, $\mathrm{NaCl}, \mathrm{BF}_{2}$ 等の結晶を製作している。 $\mathrm{BF}_{2}$ は 直径 $20 \mathrm{~cm}$ ものが供給できる。

\section{4.あとがき}

今回筆者が訪問したのは上海の研究所と福建 研究所のみであるので, 報告に不十分な所があ るかも知れないことをお断りしておく。また会 議での中国以外の発表はここでは省略した。

中国におけるこの分野の研究のバラエティー, 層の厚さは大したもので，採算が常に問題とな る米国，日本等と異なり独自の方針で研究開発 を行なってきた所に結晶作りに成功しているカ ギがあると思われた。

中国出張の機会を与えて載いた大阪大学の山 中千代衛先生に感謝の意を表します。 